\title{
Banking Competition and Efficiency: The Case of Vietnamese Banking Industry
}

\author{
Long Hau Le ${ }^{1}$, Truong An Duong ${ }^{1} \&$ Tan Nghiem Le ${ }^{1}$ \\ ${ }^{1}$ College of Economics, Can Tho University, Vietnam \\ Correspondence: Long Hau Le, College of Economics, Can Tho University, Vietnam.
}

Received: March 6, 2020

Accepted: March 28, 2020

Online Published: March 31, 2020

doi:10.5430/ijfr.v11n2p453

URL: https://doi.org/10.5430/ijfr.v11n2p453

\begin{abstract}
This paper is to investigate the impact of competition on the efficiency of the banking industry in Vietnam. Data are collected from the audited annual financial statements and the annual reports of 30 commercial banks during the period of 2010 - 2017. Lerner index is used to measure the market power of bank, while Data Envelope Analysis is employed to estimate the technical efficiency of bank. The impact of competition on the operational efficiency of commercial banks is estimated by Panel Vector Autoregressive model (PVAR). The empirical results seem to indicate that there is a positive impact of competition on the bank efficiency, which is in line with the "quiet-life" hypothesis. However, the statistical test does not confirm this at the traditional levels. Interestingly, the empirical results demonstrate a negative impact of bank efficiency on the market power of bank, and hence market competition. While this result shares the causality dimension with the "efficient structure" hypothesis, it presents an opposite sign on the causality. All these findings could be explained by the real situations and typical characteristics of the economy of Vietnam. This study has important implications for both researchers and practioners.
\end{abstract}

Keywords: bank, competition, efficiency, DEA, Lerner index

JEL Classification: G21, L12, P20.

\section{Introduction}

The impact of competition on the efficiency of banking industry has long been interested in the finance literature, and a large number of empirical studies on the topic have been conducted. In the context of deeper integration into the world economy, the financial market in general and banking industry in Vietnam in particular have been rapidly growing with a large number of commercial banks having been established. Until the end of 2019, there are more than 45 domestic commercial banks, 5 foreign-owned commercial banks, along with many branches of joint-venture banks and branches of foreign banks in Vietnam. These banks not only expand branches in major cities and economic centers of the country, but also rapidly open more branches throughout the districts and towns of most provinces in the country. This trend has made the competition in the banking industry become more and more intense than ever. In order to gain competitive advantages in the market, these banks always focus on expanding the scale, continuously introducing the modern banking technology system, offering many new products and services tailored-made for various types of customer, etc. This scenario makes the Vietnamese banking industry become an interesting research case for the topic. Particularly, this paper checks whether the increasing competition in the Vietnamese banking industry makes commercial banks become more efficiently operational.

The structure of the paper is as follows. Section 2 presents both the theoretical and empirical background of the relationship between competition and efficiency in banking industry. The data is described in section 3, followed by methodology in section 4 . Section 5 provides the empirical results and discussions. Finally, we provide some concluding remarks in section 6 .

\section{Literature Review}

Economic literature contains three strands of hypotheses addressing the relationship between firm competition and efficiency: First, the Quiet - Life hypothesis proposed by Hicks (1935) stating that the increase in competition increases economic efficiency of firms. This stems from the idea that monopoly power allows managers to take away part of the monopoly rent- the profit that monopolies get from limiting supply to raise prices without fear of competitors. However, the existence of monopoly rents does not explain managers' profit sharing settlement. Owners 
of monopoly enterprises may exert a stricter control on managers than that of competing enterprises, and thus preventing this profit sharing. Supporting the theory, Maudos \& de Guevara (2007) argues that increasing competition increases the efficiency of banks, namely the higher the market power, the lower management's effort to maximize operational efficiency. There is a negative correlation between market power and efficiency. This implies that market power reduces bank efficiency, or in other words, increases competition will increase bank efficiency. Next, the Structure - Efficient hypothesis by Demsetz (1973) predicts that economic efficiency reduces competition. It contradicts the "Quiet-life" view in terms of both the expected sign and dimension of causality. The argument is that the best management company may have the lowest costs and thus gain the largest market share. This leads to a higher level of market concentration for the company. Since market concentration can be regarded as an inverse index of competition, one can expect a negative link between competition and efficiency. Thirdly, Pruteanu-Podpiera et al. (2008) introduce the Banking Specificities hypothesis conjecturing that competition has an adverse impact on economic efficiency. While the first two views are not typical of the banking market, the theoretical literature suggests that the banking industry is special in the way it works. More specifically, theoretical literature on banking shows that the market structure in the banking industry is imperfectly competitive due to the information asymmetry in lending relationships. To minimize this problem, banks need to maintain long-term relationships with borrowers. However, increased competition means an increase in supervision costs due to economies of scale and reduces customer relationship in the long- run. This means a negative correlation between banking competition and efficiency.

Various empirical studies have been conducted on the relationship between banking competition and efficiency. Since the list of empirical research has never been exhausted, some selected studies are discussed as follows. A number of other empirical studies show a positive relation between banking competition and efficiency. Using a sample of the U.S. banks, Berger and Hannan (1998) find that, in a more concentrated market, banks are less efficient. Casu and Girardone (2009) document the same evidence for the EU banks in the period 1997-2003. Similarly, other studies also support these findings, e.g., Pruteanu - Podpiera et al. (2008), and Schaeck \& Cihák (2008) for banks in the EU and the US during 1995-2005. Chan, Koh, Zainir and Yong (2015) examine the effect of market concentration towards bank efficiency with the mediating role of institutional framework in the ASEAN-5. Consistent with economic theory, the findings show that higher bank concentration reduces the efficiency level of commercial banks. Considering the role of capital regulation, Maji and Hazarika (2018) analyze the influence of competition on risk of the banking system and find that the relationship is negative. This results support the "competition stability" view that competition may increase the bank efficiency. In contrast, several studies evidence a negative impact of competition on the bank efficiency. Weill (2004) investigates the relationship between competition and efficiency of the banking sector in 12 EU countries in the period of 1994-1999 and finds that the relation is significantly negative. Explaining for these findings, Boot and Schmeits (2005) argue that the relationship between customers and banks is unstable, and tends to be looser in a more competitive market. Moreover, higher competition increases the tendency of customers of a bank to switch to other banks. This problem increases the information asymmetry making banks more costly to maintain the relation with the customers. Analyzing the impact of competition and concentration on bank stability in the Turkish banking industry over the period 2002-2012, Kasman and Kasman (2015) indicate that competition is negatively affected the bank stability proxies by the NPL ratio and the $Z$-score. This may imply that competition could harm the bank efficiency. Phan, Anwar, Alexander and Phan (2019) examines the relationships between competition, efficiency and stability in the banking systems of four East Asian countries (China, Hong Kong, Malaysia and Vietnam) over 2004-2014. The results support the traditional competition-fragility view, and suggest that an increase in competition may result in a decrease in efficiency. Nevertheless, a group of studies finds no evidence for the impact of banking competition on efficiency. Kick and Prieto (2015) show that regulation to reduce competition does not necessarily enhance the stability of individual banks, or the resilience of banks to macroeconomic shocks. This implies that competition may not have any impact on the bank efficiency. For the Indonesian Islamic banking industry, Al Arif and Awwaliyah (2019) show that concentration does not affect the bank profitability, which does not support the efficient structures hypothesis. Furthermore, in another empirical study on the Indonesian Islamic banking industry, Al Arif, Mufraini, and Prabowo (2020) show that the increasing number of full-fledged Islamic banks does not mean that performance (measured by efficiency) will increase. Looking from another perspective, some studies test the causal relation between the banking competition and efficiency. For examples, Casu and Girardone (2009) find a causal relationship between the bank market power (an inverse indicator of market competition degrees) and efficiency for 2,700 banks from the five largest economies in EU over the period of 2000-2005. Using a sample of 272 commercial banks from 15 Latin American countries for the period of 2001-2008, Kasman and Carrallo (2014) examine the relationship between competition, risk and efficiency by Granger-causality test. The results show that greater competition leads to greater 
financial stability, which helps banks to gain greater market power. Therefore, banks with higher market power are more efficient.

In short, the theoretical links between competition and bank efficiency have long been established in the economic literature. Grounded on these establishes links, a large number of empirical studies has been implemented. Yet, as previously discussed, while some research finds a positive relationship between competition and efficiency (Andries \& Căpraru, 2014; Schaeck \& Cihák, 2008), the other studies show a negative one (Fernandez \& Maudos, 2007; Pruteanu - Podpiera et al., 2008) or even no link (Fungácová et al., 2013). This leads to the fact that the real influence of competition on the bank efficiency is still unclear.

\section{Data}

Data are collected from the annual financial reports of 35 Vietnamese Joint Stock Commercial Banks during 2010 2017. Yet, in this period some banks were merged and restructured under the request of the State Bank of Vietnam due to poor performance, therefore some necessary information was not fully reported every year by these banks. This study then comes up with a panel data of only 30 banks over an 8-year period.

\section{Methodology}

\subsection{Measurement of Efficiency}

This paper uses Data Envelopment Analysis (DEA) first developed by Charnes, Cooper and Rhodes (1978) to measure technical efficiency (TE) of banks. Following the literature, e.g., Avkiran (1999), bank outputs are measured by interest income and non-interest income (income from investments and other services of bank), while input variables include interest expenses and non-interest expenses. This approach is also applicable for the sample, since these information are fully published in the financial statements of Vietnamese commercial banks.

\subsection{Measurement of Competition}

Many methods were developed to measure the degree of market competition for firms such as Bresnahan (1982), Lau (1982), Panzar \& Rosse (1978) (known as Herfindahl index), Boone (2008) (known as Boone index), and Lerner (1934) (known as Lerner index). Among these approaches, only Lerner index and Boone index are often used to measure the banking market competition at the individual firm levels, in which the Lerner index is usually more preferable approach (e.g., see Thom \& Thuy (2015)).

A bank's Lerner-index value ranges from a maximum of 1 to a minimum of 0 with higher values indicating greater market power of this bank, and hence less competition market. The Lerner index represents the extent to which a particular bank has market power to set its price above the marginal cost. The price is computed by estimating the average price of bank production (proxies by total assets) as the ratio of total revenues over total assets. The marginal cost is estimated on the basis of a trans-log cost function with one output (total assets) and three input prices (prices of labor, prices of physical capital and prices of funds) (e.g., Fernandez de Guevara et al. (2005), Carbo et al. (2009a, b)). Lerner index is defined as the difference between a bank's output price and its marginal costs divided by the bank's output price:

$$
\text { LERNER } R_{i t}=\frac{P_{i t}-M C_{i t}}{P_{i t}}
$$

where: $\mathrm{i}$ is individual bank, $\mathrm{t}$ denotes time; $\mathrm{P}$ is a bank's average output price, calculated by dividing the total revenue to total assets; $\mathrm{MC}$ is a marginal cost of the bank, defined as first derivative of the total cost.

The bank's total cost function is estimated using the model of Fu et al. (2014) with one output and three input prices as mentioned previously. Linear and homogeneity restriction in input prices is imposed by normalizing total costs and input prices by one input price. Since panel data are used for this study, the selection between random effects and fixed effects method to estimate the total cost function is conducted using the Hausman test. Given the results of Hausman test, the fixed effects are employed for the estimation. Finally, marginal cost is estimated in two steps as follows:

Step 1: Total costs are estimated 


$$
\begin{aligned}
\operatorname{LnTC}_{i t}= & \alpha_{0}+\alpha_{1} \operatorname{lnTA}_{i t}+\frac{1}{2} \alpha_{2}\left(\operatorname{lnTA} A_{i t}\right)^{2}+\alpha_{3} \ln w_{1 i t}+\alpha_{4} \ln w_{2 i t}+\alpha_{5} \ln w_{3 i t}+\operatorname{lnTA} A_{i t} \ln w_{1 i t} \\
& +\alpha_{7} \operatorname{lnTA}_{i t} \ln w_{2 i t}+\alpha_{8} \operatorname{lnTA}_{i t} \ln w_{3 i t}+\alpha_{9} \ln w_{1 i t} \ln w_{2 i t}+\alpha_{10} \ln w_{1 i t} \ln w_{3 i t} \\
& +\alpha_{11} \ln w_{2 i t} \ln _{3 i t}+\frac{1}{2} \alpha_{12}\left(\ln w_{1 i t}\right)^{2}+\frac{1}{2} \alpha_{13}\left(\ln w_{2 i t}\right)^{2}+\frac{1}{2} \alpha_{14}\left(\ln w_{3 i t}\right)^{2}
\end{aligned}
$$

where: $\mathrm{i}$ is individual bank, $\mathrm{t}$ denotes time; $\mathrm{TC}$ is total costs (included: Interest expenses, labor expenses and the other expenses); TA is total assets; $\mathrm{w}_{1}$ denotes labor prices defined as the ratio labor expenses divided by total assets; $\mathrm{w}_{2}$ represents prices of borrowed funds defined as the ratio interest expenses divided by total deposits; $\mathrm{w}_{3}$ is physical capital prices defined as the other expenses divided by total fixed assets.

Step 2: The marginal costs for each bank is derived from taking first derivative of the total costs with respect to total assets as described below

$$
\mathrm{MC}_{\mathrm{it}}=\frac{\partial \mathrm{TC}_{i t}}{\partial T A_{i t}}=\frac{\mathrm{TC}}{T A_{i t}}\left(\alpha_{1}+\alpha_{2} \ln T A_{i t}+\alpha_{6} \ln w_{1 i t}+\alpha_{7} \ln w_{2 i t}+\alpha_{8} \ln w_{3 i t}\right)
$$

\subsection{Estimated Models}

Due to the possible mutual effects between competition and efficiency, PVAR (panel vector autoregression) model is applied to estimate the relation (see, e.g., Eakin et al. (1988)). However, the use of classical PVAR model may lead to biased coefficients, incorrect standard errors, and observations lost, hence in this study PVAR model with Generalized Method of Moment approach, introduced by Love \& Zicchino (2006), is implemented. The optimal number of lags for PVAR is chosen using the moment model selection criteria as proposed by Andrews \& Biao (2001).

Model specifications can be presented as follows

$$
\begin{gathered}
L_{E R N E R_{i t}}=f\left(T E_{i t-l a g}, L E R N E R_{i t-l a g}, X_{i t}\right)+\varepsilon_{i t} \\
T E_{i t}=f\left(T E_{i t-l a g}, L E R N E R_{i t-l a g}, X_{i t}\right)+\varepsilon_{i t}
\end{gathered}
$$

where, $\mathrm{i}$ is individual bank, $\mathrm{t}$ denotes time; TE symbolizes technical efficiency; LERNER represents for competition variable; $X_{i, t}$ is a vector containing the control variables of bank characteristics and macroeconomics variables; $\varepsilon_{i t}$ : random errors.

Definition of all control variables $\left(X_{i, t}\right)$ is as follow: Size is measured by the natural logarithm of total assets; Liquidity is defined as the ratio of total loans divided by total assets; $R O A$ is calculated by the ratio of after-tax profits divided by total assets; and $I R$ is annual inflation rates.

\section{Results and Discussions}

\subsection{The Evolution of Competition and Efficiency of the Banking Industry Over 2010-2017}

Table 1 shows the evolution of competition and efficiency of the banking industry over 2010-2017.

As can be seen from panel A of table 1, the average value of the Lerner index of all Vietnamese commercial banks ranges from 0.55 to 0.61 . The average index displays a slight uptrend, indicating that the market power of the banking system tends to increase. This implies that the banking market have a propensity to be less competitive over time.

Turning now to panel B of table 1, the average technical efficiency of commercial banks lies between 0.80 and 0.92 , and show unclear trend over time. These figures demonstrate that the average efficiency of banks in the system is relatively high. Moreover, the efficiency degree of these banks is not much different due to the small standard deviation values of efficiency. 
Table 1. Banking competition and efficiency over 2010-2017

\begin{tabular}{lcccccccc}
\hline \multicolumn{2}{l}{2010} & 2011 & 2012 & 2013 & 2014 & 2015 & 2016 & 2017 \\
\hline \multicolumn{2}{l}{ Panel A: Evolution of competition (Lerner index) } & over 2010-2017 & & & & \\
\hline Mean & 0.55 & 0.57 & 0.58 & 0.55 & 0.56 & 0.59 & 0.60 & 0.61 \\
\hline Max & 0.75 & 0.73 & 0.73 & 0.74 & 0.76 & 0.83 & 0.84 & 0.83 \\
\hline Min & 0.32 & 0.36 & 0.38 & 0.19 & 0.33 & 0.38 & 0.45 & 0.41 \\
\hline Observations & 28 & 28 & 29 & 30 & 30 & 29 & 29 & 29 \\
\hline Panel B: Evolution of efficiency (technical efficiency) over & $2010-2017$ & & & & \\
\hline Mean & 0.80 & 0.92 & 0.88 & 0.86 & 0.86 & 0.88 & 0.88 & 0.84 \\
\hline Standard deviation & 0.08 & 0.09 & 0.10 & 0.11 & 0.10 & 0.10 & 0.11 & 0.12 \\
\hline Max & 1.00 & 1.00 & 1.00 & 1.00 & 1.00 & 1.00 & 1.00 & 1.00 \\
\hline Min & 0.68 & 0.69 & 0.67 & 0.66 & 0.62 & 0.73 & 0.64 & 0.57 \\
\hline Observations & 28 & 28 & 29 & 30 & 30 & 29 & 29 & 29 \\
\hline
\end{tabular}

\subsection{Results From Panel Vector Autoregressive Model (PVAR)}

The results from PVAR are presented in Table 2. The number of optimal lags for the model is one. Fisher tests show that both TE and LERNER are stationary. In the equation explaining TE, the coefficient of 1-lagged LERNER is, not statistically significant at any traditional levels, even though it has a negative sign. Consequently, the Wald-test for the null hypothesis that LERNER does not "Granger-cause" TE is not statistically significant at these levels (See at the end of the table). These results indicate that the market power may have a negative impact on the operational efficiency of banks, meaning that increase in the market power might lead to the decrease in efficiency. In other words, in a more competitive market the banks seem to be more efficiently operational. These findings are in line with the quiet-life hypothesis and many other previous studies discussed in the literature. Furthermore, these findings are also relatively applicable for the real situation of Vietnam, i.e., as mentioned in the introduction, this period has witnessed the intense competition in the banking industry of Vietnam. This forces banks to look for the ways to increase their efficiency to keep staying in the market. E.g., during this period most of banks experienced a high rate of turnover of employees due to the efforts in increasing the efficiency by attracting skilled staffs from each other among banks. Nevertheless, the statistical evidence is not strong enough to support for this conclusion. As for the equation explaining $L E R N E R$, the coefficient of 1-lagged $T E$ shows a negative sign and is statistically significant at the $10 \%$ level. As a result of this, the Wald-test for the null hypothesis that TE does not "Granger-cause" LERNER is statistically significant at the same level as well (See at the end of the table 2). These results demonstrate that efficiency does have an effect on the market power of the bank. Particularly, efficiency has a negative impact on market power of the bank in this case, implying that the efficient banks have less market power than their less efficient counterparts do. Interestingly, these findings are in line with the efficient structure hypothesis in terms of the causality dimension (i.e. performance causes structure), but in an opposite sign (i.e. a negative versus positive sign). A possible explanation for these results may be due to typical characteristics of the economy of Vietnam. More specifically, the banking industry of Vietnam has been dominated by state-controlled and state-owned banks (e.g., known as Vietcombank, Vietinbank, Agribank, BIDV, Baovietbank, etc.). It is well known that these banks tend to have higher market power and profits due to the subsidy by the government, but commonly exhibit a lower operational efficiency than their private counterparts do. These facts could lead us to the conjecture that, in the banking industry of Vietnam, higher efficiency banks (i.e. private banks) might not always be the greater profitable ones and hence the higher market power ones. Our assumption is perhaps reinforced by the findings of Burdisso and D'Amato (1999) that, in the banking industry of Argentina, higher efficiency banks are lower profitable. While the grounded mechanism of the efficient structure hypothesis states that higher efficient banks may gain more profits at the expenses of less efficient ones, and finally grasp greater market power, this link seems hard to be established for the banking market of Vietnam. Considering all these facts, our empirical results could be easily explainable.

Regarding the control variables in both the equations, the coefficient of Size and Liquidity is statistically significant at traditional levels while that of $R O A$ and $I R$ is not statistically significant at any of the traditional levels. 
Table 2. Results from PVAR model

\begin{tabular}{lll}
\hline Dependent variable & $T E_{i t}$ & LERNER $_{\text {it }}$ \\
\hline \multirow{2}{*}{$T E_{(i t-1)}$} & Coefficients & Coefficients \\
\hline \multirow{2}{*}{ LERNER $_{(i t-1)}$} & -0.556 & $-0.385^{*}$ \\
& {$[0.418]$} & {$[0.209]$} \\
\hline \multirow{2}{*}{ Size $_{i t}$} & -0.366 & $0.245^{* * *}$ \\
& {$[0.288]$} & {$[0.069]$} \\
\hline \multirow{2}{*}{ Liquidity $_{\text {it }}$} & $-0.214^{* *}$ & $-0.083^{* * *}$ \\
& {$[0.104]$} & {$[0.032]$} \\
\hline \multirow{2}{*}{ ROA } & $1.143^{*}$ & $1.152^{* * *}$ \\
& {$[0.682]$} & {$[0.273]$} \\
\hline \multirow{2}{*}{$I R_{i t}$} & 3.664 & -3.991 \\
& {$[11.694]$} & {$[4.250]$} \\
\hline
\end{tabular}

Wald-test for $\mathrm{H}_{0}$ : LERNER does not "Granger-cause" $T E: \chi^{2}=1.63$

Wald-test for $\mathrm{H}_{0}: T E$ does not "Granger-cause" LERNER: $\chi^{2}=3.40^{*}$

No. of observations: 232

Fisher test for panel unit root for $T E: \chi^{2}=13.24^{* * *}$

Fisher test for panel unit root for LERNER: $\chi^{2}=6.77^{* * * *}$

Stability condition for PVAR is satisfied

$\begin{array}{lll}\text { P-value } A R(1) & 0.25 & 0.43 \\ \text { P-value for Sargan } & 0.003 & 0.001\end{array}$

Notes: *, ** and *** denote the significant levels of $10 \%, 5 \%$ and $1 \%$, respectively; Standard errors are reported in parentheses under coefficients.

Results from post-estimation tests are presented at the end of table 2. As can be seen from the table, the stability condition for PVAR is satisfied, indicating that estimated coefficients are stable and reliable. While the Sargan-test guarantees for the valid of instrument variables in the model, no evidence of first-order serial correlation in the residuals of both equations is statistically significantly found.

\section{Conclusions}

In conclusion, grounded on the economic literature this research examines the link between competition and efficiency in the banking sector of Vietnam over the period of 2010-2017. Following the literature, the Lerner index is used to measure the market power of banks, and the Data Envelope Analysis (DEA) is utilized to estimate the technical efficiency of banks. The results show that the banking market has a propensity to be less competitive over time, and that the average efficiency of banks in the system is fairly high. The relationship between banking competition and efficiency is estimated using a panel vector-autoregressive model (PVAR). Empirical results from the model show that in a more competitive market the banks seem to be more efficiently operational. These findings are in line with the quiet-life hypothesis, but are not strongly supported by the statistical tests. Interestingly, these results demonstrate that efficiency does have an effect on the market power of the bank, which are in line with the efficient structure hypothesis in terms of the causality dimension (i.e. performance causes structure), but in an opposite sign (i.e. a negative versus positive sign). All these findings could be explained by the real situations and typical characteristics of the Vietnamese economy.

This study has important implications for both researchers and practioners. Although the economic literature, i.e. the efficient structure hypothesis, assumes that performance has a positive relationship with bank size, this assumption 
might not always be applicable for the case of transitional economies. In these economies, the banking system is still dominated by the State-owned and State-controlled banks that are most likely favored and subsidized by the government. This study therefore provides a reverse evidence for the literature, which opens up a new perspective for future research. In addition, this study also proposes a number of policy recommendations. For policy makers and legal regulators of the banking system, since private banks may be more operationally efficient, but lower market power than State-controlled and State-owned banks, a more competitive banking market should be accelerated by legal framework to reward private banks for their excellent efforts. Moreover, this could also contribute to increase the overall efficiency of the banking system. For commercial banks, as their average efficiency tends to be decreased over the sample period, they should put more efforts in improving their businesses in the future. Especially, for private commercial banks, they should try to be as much efficient as they could to stay competitive in the market.

\section{References}

Ajisafe, R. A., \& Akinlo, A. E. (2014). Competition and Efficiency of Commercial Banks: Empirical Evidence from Nigeria. American Journal of Economics, 4(1), 18-22.

Al Arif, M. N. R., \& Awwaliyah, T. B. (2019). Market Share, Concentration Ratio and Profitability: Evidence from Indonesian Islamic Banking Industry. Journal of Central Banking Theory and Practice, 8(2), 189-201. https://doi.org/10.2478/jcbtp-2019-0020

Al Arif, M. N. R., Mufraini, M. A., \& Prabowo, M. A. (2020). Market Structure, Spin-Off, and Efficiency: Evidence from Indonesian Islamic Banking Industry. Emerging Markets Finance and Trade, 56(2), 329-337. https://doi.org/10.1080/1540496X.2018.1553162

Andrews, D., \& Biao, L. (2001). Consistent model and moment selection procedures for GMM estimation with application to dynamic panel data models. Journal of Econometrics, 101, 123-164. https://doi.org/10.1016/S0304-4076(00)00077-4

Andrieș, M. A., \& Căpraru, B. (2013). How does EU banking competition impact financial stability?. Faculty of Economics and Business Administration, Alexandru Ioan, Cuza University.

Avkiran, N. K. (1999). The evidence on efficiency gains: The role of mergers and the benefits to the public. Journal of Banking \& Finance, 23(7), 991-1013. https://doi.org/10.1016/S0378-4266(98)00129-0

Berger, A. N., Hasan, I., \& Zhou, M., (2009). Bank ownership and efficiency in China: What will happen in the world's largest nation?. Journal of Banking and Finance, 33, 113-130. https://doi.org/10.1016/j.jbankfin.2007.05.016

Boone, J. (2008). A new way to measure competition. The Economic Journal, 118, 1245-1261. https://doi.org/10.1111/j.1468-0297.2008.02168.x

Boot, A., \& Schmeijts, A. (2006). The Competitive Challenge in Banking. Advances in Corporate Finance and Asset Pricing, 133-160. https://doi.org/10.1016/B978-044452723-3/50007-3

Bresnahan, T. (1982). The oligopoly solution concept is identified. Economics Letters, 10, 87-92. https://doi.org/10.1016/0165-1765(82)90121-5

Burdisso, T., \& D'Amato, L. (1999). Prudential Regulations. Restructuring and Competition: The Case of the Argentine Banking Industry.

Carbó, S., Humphrey, D., Maudos, J., \& Molyneux, P. (2009). Cross-country comparisons of competition and pricing power in European banking. Journal of International Money and Finance, 28(1), 115-134. https://doi.org/10.1016/j.jimonfin.2008.06.005

Carbo-Valverde, S., Rodriguez-Fernandez, F., \& Udell, G. F. (2009). Bank market power and SME financing constraints. Review of Finance, 13(2), 309-340. https://doi.org/10.1093/rof/rfp003

Casu, B., \& Molyneux, P. (2003). A comparative study of efficiency in European banking. Applied Economics, 35(17), 1865-1876. https://doi.org/10.1080/0003684032000158109

Chan, S. G., Koh, E. H., Zainir, F., \& Yong, C. C. (2015). Market structure, institutional framework and bank efficiency in ASEAN 5. Journal of Economics and Business, 82, 84-112. https://doi.org/10.1016/j.jeconbus.2015.07.002

Charnes, A., Cooper, W. W., \& Rhodes, E. (1978). Measuring the efficiency of decision making units. European Journal of Operational Research, 2(6), 429-444. https://doi.org/10.1016/0377-2217(78)90138-8 
Demsetz, H. (1973). Industry Structure, Market Rivalry and Public Policy. Journal of Law and Economics, 16, 1-9. https://doi.org/10.1086/466752

Fernandez de Guevara, J., Maudos, J., \& Perez, F. (2005). Market Power in European Banking Sectors. Journal of Financial Services Research, 27(2). https://doi.org/10.1007/s10693-005-6665-z

Fu, X. M., Lin, Y. R., \& Molyneux, P. (2014). Bank competition and financial stability in Asia Pacific. Journal of Banking \& Finance, 38, 64-77. https://doi.org/10.1016/j.jbankfin.2013.09.012

Fungáčová, Z., Solanko, L., \& Weill, L. (2014). Does competition influence the bank lending channel in the euro area?. Journal of Banking \& Finance, 49, 356-366. https://doi.org/10.1016/j.jbankfin.2014.06.018

Hicks, J. (1935). The Theory of Monopoly. Econometrica, 3, 1-20. https://doi.org/10.2307/1907343

Holtz-Eakin, D., Newey, W., \& Rosen, H. S. (1988). Estimating vector autoregressions with panel data. Econometrica: Journal of the Econometric Society, 1371-1395. https://doi.org/10.2307/1913103

Kasman, A., \& Carvallo, O. (2014). Financial stability, competition and efficiency in Latin American and Caribbean banking, Journal of Applied Economics, 17, 301-324. https://doi.org/10.1016/S1514-0326(14)60014-3

Kasman, S., \& Kasman, A. (2015). Bank competition, concentration and financial stability in the Turkish banking industry. Economic Systems, 39(3), 502-517. https://doi.org/10.1016/j.ecosys.2014.12.003

Kick, T., \& Prieto, E. (2015). Bank risk and competition: Evidence from regional banking markets. Review of Finance, 19(3), 1185-1222. https://doi.org/10.1093/rof/rfu019

Lau, L. J. (1982). On identifying the degree of competitiveness from industry price and output data. Economics Letters, 10(1-2), 93-99. https://doi.org/10.1016/0165-1765(82)90122-7

Lerner, A. (1934). The concept of monopoly and the measurement of monopoly power. Review of Economic Studies, l(157), 75. https://doi.org/10.2307/2967480

Love, I., \& Zicchino, L. (2006). Financial development and dynamic investment behavior: Evidence from Panel VAR. Quarterly Review of Economics and Finance, 46(2), 190-210. https://doi.org/10.1016/j.qref.2005.11.007

Maji, S. G., \& Hazarika, P. (2018). Capital regulation, competition and risk-taking behavior of Indian banks in a simultaneous approach. Managerial Finance. https://doi.org/10.1108/MF-09-2017-0340

Maudos, J., \& de Guevara, J. (2007). The cost of market power in banking: Social welfare loss vs. Cost inefficiency. Journal of Banking and Finance, 31(7), 2103-2125. https://doi.org/10.1016/j.jbankfin.2006.10.028

Panzar, J. C., \& Rosse, J. N. (1987). Testing for "monopoly" equilibrium. The Journal of Industrial Economics, 443-456. https://doi.org/10.2307/2098582

Phan, H. T., Anwar, S., Alexander, W. R. J., \& Phan, H. T. M. (2019). Competition, efficiency and stability: An empirical study of East Asian commercial banks. The North American Journal of Economics and Finance, 50, 100990. https://doi.org/10.1016/j.najef.2019.100990

Pruteanu-Podpiera, A., Weill, L., \& Schobert, F. (2016). Banking competition and efficiency: A micro-data analysis on the Czech banking industry. In Global Banking Crises and Emerging Markets (pp. 52-74). Palgrave Macmillan, London. https://doi.org/10.1007/978-1-137-56905-9_4

Schaeck, K., Cihak, M., \& Wolfe, S. (2006). Are competitive banking systems more stable?. Journal of Money, Credit and Banking, 41(4), 711-734. https://doi.org/10.1111/j.1538-4616.2009.00228.x

Thom, P. T., \& Thuy, T. T. T. (2015). Competition on the Vietnamese commercial banking system: A comparison between traditional approach and modern approach. Journal of Economic Development, 26(7), 28-46.

Weill, L. (2004). On the relationship between competition and efficiency in the EU banking sectors. Kredit und Kapital, 329-352. 